\title{
Predisposed to risk but not change
}

I $\mathrm{n}$ the field of genetic medicine, knowing and doing appear to have little in common besides ending in "ing". Advocates for direct-to-consumer genetic testing have long argued that providing people with data about their predispositions toward health risks would motivate them to adopt healthier behaviours to reduce those risks. But it seems that the power of knowledge pales in comparison to the power of honey-glazed crullers.

Human behaviour is complex and, at times, far from rational. Altering behaviour, especially a habit practised for so long as to be cemented into a lifestyle, is no easy task. It would be naive, for instance, to believe that fast food fanatics would suddenly switch to kale and tofu because a test indicated there was a chance they might one day develop obesity-related conditions.

"I can't even get some patients who already have a condition to change their behaviour," says Dr. Arya Sharma, professor of medicine and chair in obesity research and management at the University of Alberta in Edmonton.

Anyway, people don't really need a genetic test to realize they are at risk for developing an obesity-related health problem, says Sharma. If their waistlines don't tell the whole story, their family histories can fill in the gaps. If a parent and an uncle and an aunt have all had strokes, for example, you don't need test results to know that stroke is something you should be concerned about. Besides, digging for a few genes to blame for obesity and its associated ills might be a wasted effort in a burger-and-fries world where food contains loads of fat, heaps of sugar and more salt than a Canadian highway in February.

"Putting on weight in a society like ours is the natural result of living in a society like ours," says Sharma.

Furthermore, the behavioural changes most often suggested to ward off the health catastrophes foreshadowed in genetic tests are things people should be doing anyway, such as exercising more

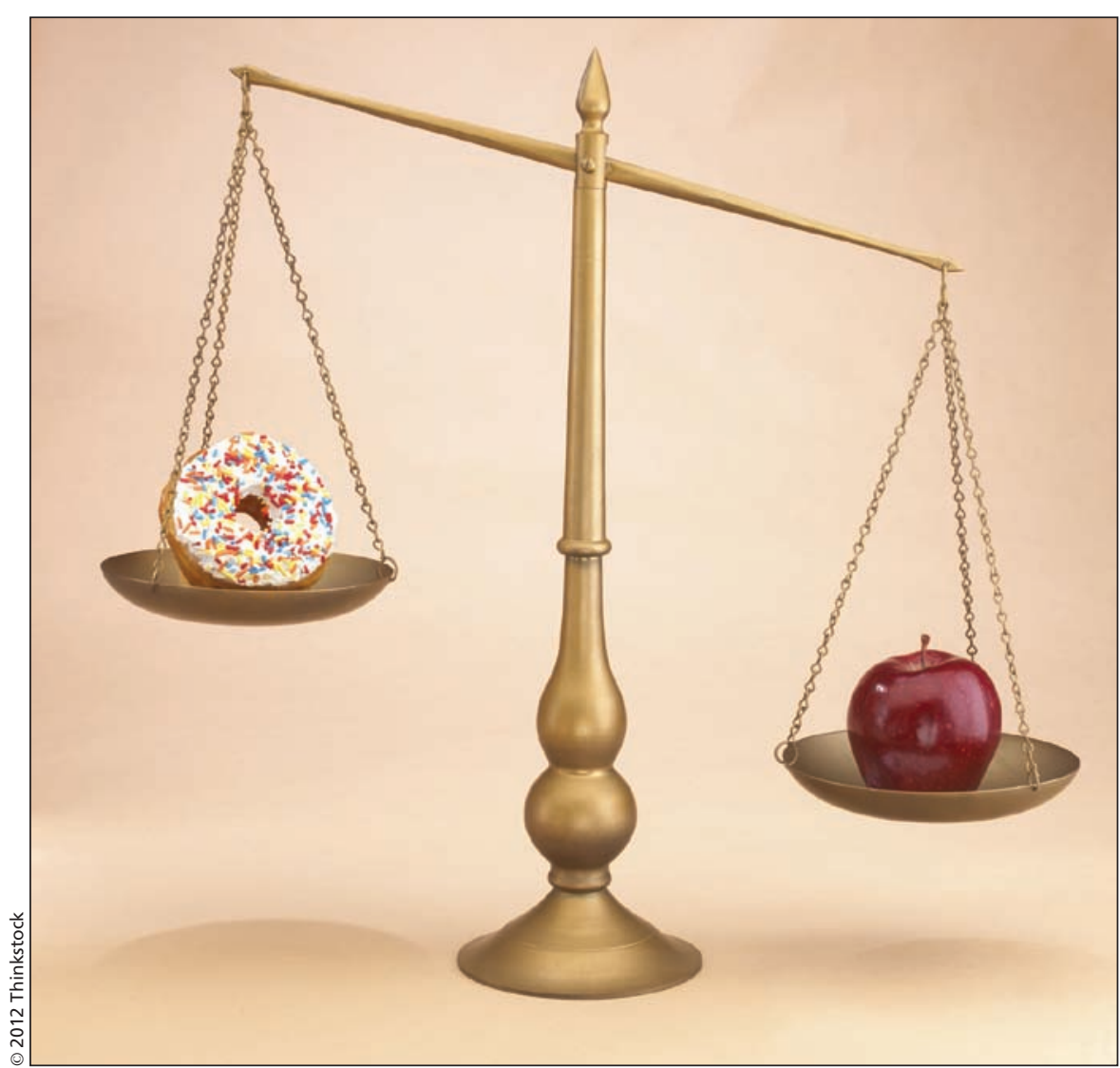

When it comes to genetic testing, it seems the power of knowledge pales in comparison to the power of a vanilla-dipped doughnut, complete with sprinkles.

and eating less. Many of the chronic illnesses that are increasingly a burden to society might best be described as fork-related problems. It's not as though people don't already know the steps necessary to reduce health risks. "I don't need a genetic test to tell me to eat healthy," says Sharma.

Another hole in the knowledge-ispower theory - one conveniently ignored by some genetic testing enthusiasts - is that many people who already have healthy lifestyles will discover they are not predisposed to particular health risks and may cut back on the cardio and bean sprouts. "A critical point that people miss is that the motivational power of something like genetic information cuts both ways," says Dr. James Evans, editor-in-chief of Genetics in Medicine and Bryson
Distinguished Professor of Genetics and Medicine at the University of North Carolina in Chapel Hill. "The clear corollary of saying people at increased risk will adopt healthier behaviours is that the other half of people found to be at decreased risk are going to become complacent."

That said, such discussions are grounded only in theory. In truth, as a body of research is showing, presenting patients with genetic information does little to change their behaviour. "We have clearly shown this over and over. It is no magic bullet. There is no great harm of making people complacent and no great benefits to motivation," says Evans. "We have to get over this idea that providing genetic information to people is a great motivating factor. It doesn't do much to change people's behaviour." 
In 2001, a review of research on this topic found that the existing evidence "suggests that providing people with DNA derived information about risks to their health does not increase motivation to change behaviour beyond that achieved with non-genetic information" (BMJ 2001;322:1056). A more recent systematic review of studies about the impact of receiving personalized genetic information on how people perceive the amount of control they have over particular health risks (obesity, heart disease, depression and diabetes) found that the evidence shows "no impact of personalized genetic risk information on perceived control in either the short term ... or longer term" (Genet Med 2011;13:273-7).

Of course, considering that the predictive power of genetic testing tends to be underwhelming, perhaps it's no surprise that personalized genetic information induces more shoulder shrugs than lifestyle changes. "One of the challenges is that people are behaving rationally, to a degree, when they don't change their behaviours. These genetic tests aren't very predictive," says Timothy Caulfield, a Canada Research Chair in Health Law and Technology who teaches in the law faculty and school of public health at the University of Alberta. "If you find you have a health risk of $2 \%$ instead of $1 \%$, that type of risk is lost in the noise of risk in your life." - Roger Collier, CMAJ

CMAJ 2012. DOI:10.1503/cmaj.109-4157

Editor's note: Sixth of a multipart series on genetic testing.

Part 1: Separating hype from reality in the era of the affordable genome (www.cmaj.ca/lookup/doi/10.1503/cmaj.109-4143).

Part 2: Popping the genetics bubble

(www.cmaj.ca/lookup/doi/10.1503/cmaj.109-4142).

Part 3: Who should hold the keys to your DNA? (www.cmaj.ca/lookup/doi/10.1503/cmaj.109-4141).

Part 4: A race-based detour to personalized medicine (www.cmaj.ca/lookup/doi/10.1503/cmaj.109-4133).

Part 5: Race and genetics in the doctor's office

(www.cmaj.ca/lookup/doi/10.1503/cmaj.109-4134). 